\title{
Access to Quality Postgraduate Education through Distance Education in Ethiopia: The Case of Indira Gandhi National Open University
}

\author{
Melese Mekasha Woldeyes
}

Email:melesemm@gmail.com

\author{
Prof. M. T. Chika Sehoole \\ University of Pretoria, May 2014 \\ Email: chika.sehoole@up.ac.za
}

\section{Doi:10.5901/jesr.2015.v5n1p159}

\begin{abstract}
This paper examines the role of cross-border distance education institutions in providing access to quality postgraduate education in Ethiopia, using the Indira Gandhi National Open University (IGNOU) as a case study. It draws on the development of distance education and it further explores the potential of a distance education programme delivery system in an Ethiopian context. In addition, the study explores the policy gap between conventional and distance education in relation to international postgraduate distance education. Two instruments were used to gather relevant data, namely: interviews and document analysis. Three quality indicators, coherence, efficiency and the impact of distance education, were used as tools of analysis.
\end{abstract}

Keywords: Access, quality, Higher education, delivery mode, distance education, distance education generations, qualitative method, quality assurance, conventional education, student support services.

\section{Introduction}

Over the years higher education in Ethiopia has faced a problem of under-development which found expression in the neglect of higher education by successive governments since the turn of the $20^{\text {th }}$ century. Some of the features of the system include inequitable access to higher education; outdated curriculum; and poor quality education. Currently, higher education faces problems associated with the relevance of programmes of studies and research, equity, resource constraints and the inefficient utilisation of resources (Bogale, 2006). The result is that access to higher education opportunities, in general, and postgraduate education, in particular, has been limited. This has necessitated a need to look at alternative means of providing higher education.

Globally, higher education has been expanding over the last few decades and, according to Altbach et al. (2009), it has struggled to meet demand. A UNESCO (2003) report confirms that many countries have experienced higher rates of expansion and student enrolment than anticipated. New, non-traditional learners have also appeared on the scene; these are "mature" students, i.e., those who are 30 years and over, who either missed the opportunity of benefiting from higher education; who want to improve their qualifications; or who desire a career change. Lifelong learning is now a common trend worldwide. This mass demand for higher education is creating a great pressure on systems and institutions which are required to provide higher education of quality and relevance to the many students who are seeking to improve their lot in life by means of higher education.

Over the past decade the same trend in a rapidly growing demand for tertiary education has been seen in most African countries. For example, in Uganda enrolments grew from 20,000 in 2001 (Musisi, 2003) to close to 180,000 in 2011. In Ethiopia there was an increase from 79,000 in 1991 to more than 600,000 students in the higher education system in 2012 (Teferra, 2014) and in Kenya enrolments in state universities have risen by $41 \%$ in two years - from 195,428 in 2012 to 276,349 by the end of 2013 (Nganga, 2014). However, the increased enrolments have not been accompanied by investment of resources and this has had serious implications for quality.

Globally, different means of providing higher education have been explored as a result of the realisation of the inadequacy of traditional contact institutions to meet the increasing demand for higher education. Generally, distance education is viewed as alternative mode of higher education provision. In making a case for distance higher education, in its White Paper for Post School Education and Training System (2014) the Department of Higher Education and Training 
in South Africa notes that in recent years distance education has become a vital part of the university sub-system, responsible for approximately $40 \%$ of headcount students and about $30 \%$ of FTE students. It has provided extensive opportunities for students who were unable, or did not want, to participate in campus-based and fixed time study; it also includes provision of access for those who experience a range of barriers to learning.

Distance education is no longer offered by national institutions only; it has taken on an international dimension with cross-border institutions being involved in the provision of education in areas where there is a need. Knight (2007) explains the cross-border mobility of providers as the physical or virtual movement of an education provider (institution, organisation or company) across a national border to establish a presence which offers education/training programmes and/or services to students and other clients. The overall demand for higher and adult education, especially professionally related courses, is increasing in most countries. There are a number of reasons for this, including changing demographics; an increased number of secondary school graduates; the movement to lifelong learning; and the growth of the knowledge economy. However, the capacity of the public sector to meet this growing demand is being challenged (Knight 2006). While the international mobility of students and scholars is a long-standing form of academic mobility, it has been over the past two decades only that a greater emphasis has been placed on the movement of educational programmes, higher education institutions and new commercial providers across national borders.

Given the less developed nature of higher education systems in developing countries, many of these countries have become targets of cross-border providers who capitalise on the incapacity of governments to meet the growing demand for higher education. This article focuses on the role of a distance cross-border higher education provider, namely, Indira Ghandi National Open University's (IGNOU) role in providing access to postgraduate education through distance education. It addresses the following research question: "How can distance education enhance access to quality postgraduate education in Ethiopia?"

It is argued that given the constraints of resources to provide adequate access to higher education, IGNOU plays an important part in providing access to quality education which would not have been possible through the traditional contact mode of delivery. In developing this argument the following issues are addressed: evolution of higher education in Ethiopia; distance education policy; and cross-border policy in Ethiopia.

\section{Literature Review}

Access to higher education is no longer only through the traditional face-to-face method as an alternative has been devised in response to demands for access. An ever-growing world population; an increase in the complexity of all aspects of life; increasingly higher education requirements for almost all types of jobs; accelerating change in practically all occupations and jobs; and the special educational needs of disadvantaged and minority groups have all put pressure on the pursuit of an alternative means of access to higher education.

All these factors have contributed to the emergence and relevance of distance education (Grant, 2010; Cabuk, 2013). The economic strength of a nation depends on how many of its citizens have access to higher education and by means of distance education there is a promise of social change and cohesion by implementing its programmes at different educational levels (Morley, 2000). following:

The literature review for this study, related to access to quality postgraduate distance education, shows the

- Distance education, now taken as revolutionary and related to justice and equity, allows for the access of previously disadvantaged groups of people, including women (Nuan, 1996), to higher education opportunities - which is the case in many African countries, including Ethiopia.

- According to Roper and Shaw (1993), quality in distance education is seen as meeting the requirements and expectations of clients who, as in the case of this study, are students and employers. It is possible to arrive at an explicit and realistic set of quality requirements which can be guaranteed to be achievable.

- Quality is judged by assessing the degree to which the intended outcomes are achieved. Higher education institutions, both traditional and distance ones, have a responsibility to achieve and maintain the quality of their educational programmes as well as assure of that quality.

- Quality in higher education embraces three main elements, namely: input, process and outcomes (Dare, 2005). Input includes the key players - the learners, the academics and the administrative staff - with the necessary facilities for teaching and learning; process is the teaching and learning of various activities; and the outcomes are the graduates and acquired skills and training.

- In quality teaching and learning - unlike other services and industries - the quality of the product and the 
learner outcome is not wholly within the control of the educational institution as it can only control the process.

- Learner contributions are vital and, therefore, they should be embedded in the stated quality requirements. Through negotiation educational institutions will arrive at a quality contract or quality entitlement owned by the learners and the provider institutions. According to Roper and Shaw (1993), quality in teaching and learning is about perfection, inspiration, conforming to requirements, and fitness for purpose, improving customer or client satisfaction and empowering the customer.

Satisfying the learners' needs and requirements by providing quality higher education can help to bring about the desired economic and social development of a country by producing a quality workforce.

\section{Theoretical Framework}

This research adopted a conceptual framework based on aspects of the quality assessment of open and distance education identified by Latchem and Jung (2007) and Perraton (2000) which, in turn, was based on the assessment practices of assuring quality in Asian open and distance learning. Their initial attempt was, mainly, to examine the various quality assurance approaches employed in Asian open and distance learning universities.

Latchem and Jung (2007) and Perraton (2000) made some important suggestions about how to encourage and achieve a culture of quality in distance education which is relevant to all developing countries, including Ethiopia. Therefore, their conceptual framework has shaped the study and its results with regard to assessing the quality of postgraduate distance education provided by the cross-border host institution, IGNOU, in Ethiopia.

The theory provides the determining factors for the quality of delivery methods which can be applied, specifically, to distance education teaching and learning and to further systematic moves to conventional face-to-face approaches. It brings together the three quality indicators chosen for this study, namely: coherence, efficiency and impact. In terms of a summary of the indicators, the first of the quality indicators, 'coherence', relates to national education policies regarding distance education development and the private sector. It was found that IGNOU followed the country's higher education policy and guidelines to operate in Ethiopia in partnership with local private higher institution. 'Efficiency' is the second quality indicator used to assess the institution's various activities, including the quality of course material, student support services and learner assessment methods. The third quality indicator, 'impact', is concerned with the assessment function of the various stakeholders' perceptions, including the MoE, HERQA and the key players in the study - the graduates of MARD, current student and staff members. The perceptions of the participants differed regarding the quality of IGNOU's postgraduate programmes.

\section{Background to Higher Education in Ethiopia}

For many centuries education in Ethiopia was dominated by the Ethiopian Orthodox Church until secular education was adopted in the early 1900s. Higher education was only initiated in 1950 with the establishment of the Addis Ababa University College. No real improvement in education was observed during Emperor Haile Selassie's regime from 1930 until 1974; it only produced one university college, namely: the Addis Ababa University College. The Soviet-backed military junta, the "Derg", led by the Mengistu Haile Mariam regime which took over and ruled the country from 1974 to 1991, established four university colleges. They were, in many ways, mainly dependent on Addis Ababa University which played a leading role in their establishment; their curriculum design and development; and their staff recruitment.

Generally, higher education in Ethiopia was neglected and, consequently, became underdeveloped. Currently, it faces problems associated with the quality and relevance of programmes of studies and research, equity, resource constraints and an inefficient use of resources. The universities' contributions to the development of the country, particularly in the large number of the human resources required for development, are insufficient (Bogale, 2006). The education system in Ethiopia has faced a number of problems, including inequality, inaccessibility, the irrelevance of the old education system and low quality. After acknowledging the undeveloped status of higher education in the country, the present Ethiopian government introduced reforms in the system to enable higher institutions to contribute to the development of human resources needed for the social and economic development of the country.

As a result, new higher education reform policies were adopted in Proclamation No.351 of 2003 and Proclamation No.650 of 2009. For the first time, following the implementation of these reforms, higher education institutions became autonomous and were able to run and manage their own affairs, including appointing their own academic vice-presidents and institutional managers. The main reason for restructuring the Ethiopian education system was to bring about a desired quality of standard and a relevant system for the economic development of the country - an aspect which was not 
recognised by the old education system. Thus, the major focus of higher education in the country should be to provide quality and relevant education.

Since its inception the effects of this new education and training policy include a significant increase in the number of higher institutions and - as a consequence - the enrolment rate and participation of female students in higher education. The following table illustrates the increase in postgraduate education enrolment rates, including those of the non-government higher educational institutions in the country - especially in postgraduate programmes. Table 1 presents the enrolment trends in postgraduate programmes in higher institutions for both public and private higher educational institutions.

Table 1: Enrolment Trends in Postgraduate Programmes in Higher Education Institutions by Ownership and Year

\begin{tabular}{|c|c|c|c|c|c|c|c|c|c|}
\hline \multicolumn{5}{|c|}{ Public or Government } & \multirow{2}{*}{\multicolumn{2}{|c|}{$\begin{array}{c}\text { Non-Government } \\
\text { Master's }\end{array}$}} & \multicolumn{3}{|c|}{ Total } \\
\hline \multicolumn{3}{|c|}{ Master's } & \multicolumn{2}{|c|}{$\mathrm{PhD}$} & & & \multirow{2}{*}{ Total } & \multirow{2}{*}{ Female } & \multirow{2}{*}{$\%$ Female } \\
\hline Year & Total & Female & Total & Female & Total & Female & & & \\
\hline $2007 / 08$ & 7,211 & 702 & 258 & 7 & - & - & 7,469 & 709 & 9.5 \\
\hline $2008 / 09$ & 9,436 & 1,069 & 325 & 26 & 364 & 51 & 10,125 & 1,146 & 11.3 \\
\hline $2009 / 10$ & 12,621 & 1,485 & 791 & 47 & 860 & 171 & 14,272 & 1.703 & 11.9 \\
\hline $2010 / 11$ & 18,486 & 2,490 & 789 & 99 & 875 & 193 & 20,150 & 2782 & 13.8 \\
\hline 2012 & 22,804 & 4,635 & 1849 & 319 & 1,007 & 228 & 25,660 & 5182 & 20.2 \\
\hline
\end{tabular}

(Source: MoE, Statistical Abstract, 2011/12)

The above table shows a significant increase in postgraduate enrolments, both in public and private higher educational institutions in Ethiopia. The percentage of female postgraduate students in the country also indicates a significant improvement from $9 \%$ in 2007 to $20.2 \%$ in 2012. The sharp increase in enrolment was because of the private higher education sector, including distance education. However, tertiary enrolments in Ethiopia remain significantly low compared to other developing countries. Currently, they stand at $1.5 \%$, suggesting that more needs to be done to develop alternative means of education, including distance education. Therefore, government needs to attract more private investors, especially in the higher education sectors. In Ethiopia, as in other African countries, distance education could facilitate the advancement of human resource development at different levels.

\section{Distance Education in Ethiopia and Around the World}

The Ethiopian Distance Learning Association (EDLA) and the International Open College of Ethiopia (IOCE) have observed that if the country aims to improve the living conditions of its people through education, then it should recognise and acknowledge an inevitable paradigm shift from a traditional face-to-face system of education to a system of distance education (Nwuke, 2008:76). However, in Ethiopia the national education policy has overlooked distance education despite the role it plays in responding to society's needs for access to higher education. Thus, higher education - through distance education - is deemed to be necessary in order to improve the education system to respond to the ever-growing human resource needs of the country (Fayessa, 2010). It is argued that distance education offers an alternative delivery system that could meet the envisaged demand for quality human resources in Ethiopia.

Throughout the world problems exist which include ever-growing populations; increases in the complexity of all aspects of life; increasingly higher educational requirements for almost all types of jobs; and a need for technical skills to function effectively within a knowledge economy. Due to an inefficiency to meet all these challenges by means of traditional face-to-face education, in the future distance education will be more expansive in its use of new technologies to reach more people in rural and urban settings (Matkinw, 2010:39). In order to cope with the increasing need for higher education in a context of diminishing resources, many countries have resorted to distance education as an alternative means of accessing higher education. Today, many worldwide mega universities provide distance education as a single mode of delivery system. The following table, Table 2, illustrates the current higher enrolment rate in distance education in different countries. 
Table 2: Mega Universities throughout the WorldOffering Various Courses in Distance Education

\begin{tabular}{|l|l|c|c|}
\hline Country & Institution & Established & Enrolment \\
\hline India & Indira Gandhi National Open University & 1985 & 3.5 .million \\
Pakistan & Allamaiqball Open University & 1974 & 3.2. million \\
China & Open University of China & 1979 & 2.7. million \\
Turkey & Anadolu University & 1982 & 884,081 \\
Indonesia & University of Terbuka & 1984 & 646,467 \\
Bangladesh & Open University of Bangladesh & 1992 & 600,00 \\
South Africa & University of South Africa & 1873 & 328,179 \\
Korea & Korean National Open university & 1982 & 210,978 \\
UK & The Open University of the United Kingdom & 1969 & 203,744 \\
Iran & Payame Noor University & 1987 & 183,000 \\
Thailand & Sukhothai Thammathiratou & 1978 & 181,372 \\
Spain & Universidad Nacional de Educion a Distancia & 1972 & 180,000 \\
\hline
\end{tabular}

(Source: Allen and Seaman, 2012)

The Indira Gandhi National Open University of India is the largest distance university in the world. Founded in 1985, the university offers 310 degree programmes in arts, science, commerce, social sciences and information technology in 21 schools. It is the biggest university in the world with more than four million students in India and in 36 other countries. It has a well-established infrastructure to cope with the large number of students, including about 36000 academic counsellors, 67 regional centres, about 3000 learner support centres and 67 overseas centres. The university has 420 faculty members and academic staff and it is considered to be a world leader in distance education (http://www.squidoo. com/top-10-distance-learning-universities-inthe-world).

Allamalqball Open University in Pakistan is the second largest Open University with a total of 3.2 million students. The University of South Africa (UNISA) - the oldest distance education university, founded in 1873 - had 328,179 student enrolments in 2012. The above table shows that the highest enrolment rate is found in developing countries. For example, China, India and Pakistan are the three leading countries in terms of distance education student enrolments. However, as described above, the number of the distance education institutions in developing nations is small when compare to the so-called developed countries. When offered the chance, distance education became an option for many African adults as a means of pursuing their academic careers due to its merits and the quality of the distance education programmes (Pityana, 2004).

\subsection{Cross-Border Education Provision through the Distance Mode in Ethiopia: Indira Gandhi National Open University (IGNOU) in Ethiopia}

As indicated in the previous section, IGNOU is one of the international institutions which offer postgraduate-level distance education programmes in Ethiopia. However, IGNOU is not the only cross-border distance education provider in the country as there are some other international providers as well. The University of South Africa (UNISA), for example, is one of those which - in collaboration with the Ministry of Education - has been operating in Ethiopia since 2006 and has contributed to the capacity building and human resource development needs of the country. In Ethiopia UNISA is known as a regional learning centre for East African countries. Collaboration between UNISA and the MoE was established through the initiative of two statesmen: the former President of South Africa, Mr Thabo Mbeki, and the late Prime Minister of Ethiopia, Mr Meles Zenawi (UNISA-Ethiopia Newsletter, 2011).

The choice of IGNOU, as a case study, is based on the fact that IGNOU is one of the largest universities in the world which provides higher education opportunities by means of a distance mode to local, national and international students. It is one of the leading educational institutions in Ethiopia with a high number of postgraduate students, compared to other private universities in the country. It offers nine Master's programmes, including a Master's in Rural Development. The nine Master's programmes in Addis Ababa, Ethiopia are, namely: Master of Business Administration; Master of Commerce; Master of Arts in Public Administration; Master of Arts in Rural Development; Master of Arts in Economics; Master of Arts in Sociology; Master of Arts in Political Science; Master of Arts in Social Work; and Master of Arts in Tourism Management. During 2011/12 the enrolment in all nine Master's programmes was over 4,000 (IGNOU, 2012).

The focus on the Master's in Rural Development for this study was based on the fact that a large part of the 
Ethiopian population (85\%) is engaged in agricultural work and lives in rural areas (Tesfaye, 2010). As result, an education programme that has a focus on rural educational development will have some relevance in this context, especially in meeting the human resource needs of the country.

The majority of the students in the various postgraduate programmes are, mainly, working or professional people who would like to further their studies while working and attending family matters. Table 3, below, reflects the enrolment and the number of students who have graduated since IGNOU's inception in 2006 in Addis Ababa, Ethiopia.

Table 3: IGNOU Student Data in Addis Ababa, Ethiopia, from July 2006 to January 2012

\begin{tabular}{|c|c|c|c|c|}
\hline S/N & Programme & Registered Students & Graduated students & Active Students \\
\hline 1 & MARD & 577 & 199 & 378 \\
\hline 2 & MBA & 473 & 64 & 409 \\
\hline 3 & MCOM & 494 & 48 & 446 \\
\hline 4 & MEC & 769 & 82 & 687 \\
\hline 5 & MLIS & 11 & 3 & 8 \\
\hline 6 & MPA & 518 & 79 & 439 \\
\hline 7 & MSO & 873 & 273 & 600 \\
\hline 8 & MSW & 400 & 9 & 391 \\
\hline 9 & MPS & 7 & 1 & 6 \\
\hline Total & 9 & 4122 & 758 & 3364 \\
\hline
\end{tabular}

(Source: Compiled from data received from IGNOU and SMUC, 2012)

Some programmes, like the Master of Art in Political Science, have very few students. Among the largest number of enrolments is the Master of Art in Rural Development (MARD). The focus of this study has a relatively significant number of graduated and active students - as is shown in the above table. A large number of the participants shown in the above table attended the Master of Art in Public Administration (MPA) which trains many public and private sectors administrators for participation in the country's various levels of governance.

\section{Discussion of Findings}

The purpose of this article is to critically examine the extent of access to quality postgraduate education through distance education in Ethiopia. It is assumed that the role of cross-border distance education providers is important in enhancing access to the opportunities available in higher education.

The findings of the study were systematically analysed to build an argument, using factors from the analysis and an interpretation of the major themes which were sub-divided into three core parts. Quality assurance practices in both distance and conventional higher education of the country were highlighted and the study's quality indicators, namely: coherence, efficiency and impact were systematically dealt with. The first indicator, 'coherence', was linked to the national education policy which includes HERQA's quality enhancement policies; the second, 'efficiency', to pedagogy issues; and the third, 'impact', to the perceptions of the various stakeholders regarding IGNOU.

\subsection{Education Policy and its Implications for the Development of Distance Education}

Education policy and its implications for the development of distance education is related to the investigation of the involvement of the private sector and, specifically, how cross-border distance education providing institutions, in general, have responded to the higher education sector policy in the country. This part of the discussion includes HERQA's policy and strategic guidelines as well as IGNOU's quality enhancement policy, strategic plans and procedures - in line with the first quality indicator of the study known as 'coherence'. Evidence from the data analysis and the literature supports the opinion that Ethiopia's higher education sector is, in general, underdeveloped and that distance education, in particular, does not sufficiently respond to demand. The education policy should promote access to all types of education in Ethiopia, including distance education. However, in the policy documents distance education has been overlooked and neglected. It is interesting that in the national education policy document of Ethiopia the flexible aspects of education are implied but not clearly stated and they are, therefore, lost in implementing policy.

Globally, distance education has been rapidly accepted; it has become a priority in many countries; and, 
furthermore, it has changed the lives of many people - both in developed and developing nations. According to Dooley (2005:262), for instance, in Australia, Europe, South Africa, China, Greece and Turkey, distance education is perceived as a tool or vehicle to reach the people, especially in rural areas to improve their well-being and economic sustainability. This is also applicable to Ethiopia which has a majority of its population in the rural areas where distance education could be an alternative means to accessing higher education.

It can be argued that distance education has a potential to offer alternative means of access to higher education. The practices of the distance teaching institutions in Ethiopia have been adversely affected by a lack of national policy guidelines which should provide set standards of practice. Therefore, a comprehensive education policy that promotes the development of open and distance education in the country is needed to alleviate this problem. Thus, the majority of participants in this study suggested that the Ethiopian government should develop a clear policy on distance education programmes and, thereby, ensure its quality.

\subsection{The Institutional and Pedagogical Practices at IGNOU}

This section assesses and analyses IGNOU's provision of increasing access to postgraduate education for the workforce of the country and, thereby, contributing to the human resource development needs of the country. It is related, to the second quality indicator, 'efficiency', which focuses on the learners, staff and the various support services which could be provided to postgraduate students, including course materials, quality assessment and evaluation methods. These were systematically commented on as follows:

\subsubsection{Quality of course materials}

Quality in distance education is perceived in relation to course materials and services and, in this study, it is used for 'fitness for purpose'. Most student participants expressed positive perceptions of the quality of their course materials. The students specifically maintained that they depend, mostly, on tutorial materials for study purposes - something which they found practically useful. Relevant and quality course and study materials enrich the quality of education offered by distance education institutions (Taylor, 2001). Since open-learning and distance education teaching and learning mechanisms need to be student-centred, course and study materials are of primary importance for the achievement of this purpose. The quality of course materials at IGNOU was confirmed to be good by the MoE and HERQA participants.

However, the general view was that there is a need to supplement the printed materials, adopted by IGNOU as the main teaching media, with audio and video tapes. There were also a few students and officials who commented on the content of the course materials and suggested that there was room for further improvement. Comments that the course materials and content, which were dominated by the Indian context, need to be changed to be more relevant in the Ethiopian context were based on the responses in the interviews. One student participant commented:

"No doubt about the quality of course materials, the course description in the modules were found useful, selfexplanatory, but some of them are hard to internalize until we get further explanation in the tutorial sessions. Although the quality of course material is commendable, the Indian context in some courses still needs to be changed into theEthiopian context."

\subsubsection{Quality of student support services}

According to Kishore (1998) and Mills (2006), ensuring access to, and quality of, student support services is part of the educational institution's major responsibilities. The majority of the student participants rated the services rendered by the administrative staff at IGNOU, especially at the local level, as generally satisfactory. However, there were some students who commented that the support they received from headquarters in New Delhi was not to their satisfaction and this was something which needs greater attention and improvement by the institution. As one student participant, whose views were supported by fellow students, said:

"The final exam is marked and assessed from headquarters in New Delhi and sent to the partner institutions later. But the return of the feedback normally takes two months and sometimes more. I think it needs further improvement to have the student feedback with in shorter time's frames."

At IGNOU the student support services are organised from head office in conjunction with the partner institution. 
However, at the time of gathering this data IGNOU did not have a single branch office in any of the regional centres outside Addis Ababa. In this regard, it appears that the institution seems to be saving costs by not expanding services beyond Addis Ababa. It had no branches or centres to make the student services more accessible - even in highly populated regions - which call for improvement.

If IGNOU wants to satisfy the educational needs of the people who are seeking alternative means of access to higher education, it should, arguably, do more to establish branches of learning centres - at least in the bigger regional centres where many distance education students are living and working. The success of distance education to provide required and relevant levels of student support services in terms of administration and academic supports is, therefore, vital.

\title{
6.2.3 Quality of assessment and evaluation
}

Assessment is recognized as a key motivator of learning and an integral part of teaching and learning. Detailed feedback to students' assignment and written work is seen as an important means of learner support. Monitoring the performance of distance education is relevant as this mode of education is learner-based.

The findings of this study point to the fact that the assessment methods used at IGNOU are sub-divided into three parts, namely: self-assessment and formative and summative evaluation. In terms of the IGNOU learners' assessment methods, assignments and projects that are seen as part of formative assessment techniques comprise $30 \%$ of the total or semester results and the end of term examination makes up $70 \%$ of the final semester result. However, the majority of students confirmed that the formative and summative assessment methods of evaluation at IGNOU were very rigid and strict. The student participants said they had to complete four to six assignments by prescribed due dates before they were allowed to write their term-end examinations. In relation to this, some students indicated that their results from head office in India took an average of two to three months to reach them which they felt was a weakness and suggested that this be an issue that should be given further attention. Regarding feedback for the final examination, the student participants had the following to say:

\begin{abstract}
"...After we did our final exams, which they call it normally the term-end exams and which is taken twice a year at all host and partner institutions at different places but in the same times. This final exam is marked and assessed from headquarters in New Delhi and sent to the partner institutions later. But the return of the feedback normally takes two months and sometimes more. I think it needs further improvement to have the student feedback with in shorter time's frames."
\end{abstract}

Therefore, the institution needs to look into this matter as it also, partially, affects the quality of distance education. Furthermore, it was suggested that IGNOU's and HERQA's assessment methods should include the practice of collecting feedback from the labour market through tracer studies to catalogue employers' perspectives as well as comments from professional organizations. It was also suggested that further research and improvement in this area is needed.

\subsection{Perceptions of Stakeholders of the Quality of Postgraduate Level Distance Education}

Here the key players were students and officials at different levels of the institution, including tutors and general decisionmaking bodies at IGNOU. This study revealed that there was a general consensus among graduates and faculty members regarding the achievements of the MARD programme and the acceptance of its graduates in the workplace. This was analysed in relation to the third quality indicator, 'impact'. The findings indicate an acceptance of the graduates in the workplace in terms of their successful completion of this programme. However, IGNOU's and HERQA's assessment methods should include the practice of collecting feedback from the labour market through tracer studies by cataloguing employers' perspectives as well as comments from professional organisations.

There is a sense that increasing access to higher education, in itself, may be perceived as important and equivalent to quality in higher education. Some participants did not fully agree that quality postgraduate education was being provided by IGNOU. Rather, there were comments that the MoE should seriously follow-up and monitor the relevance and quality of this sector. For instance, the following perspective was given by MoE participants:

"Well, the perception has to be based on experiences; however, as educational experts we need to know HERQA and MoE's evaluation results on IGNOU's postgraduate education quality. First and foremost, according to my knowledge, 
the cross-border provider's motive, priority and relevance have to be assessed; whether these providers are providing higher education according to its relevance and quality required to the satisfaction of the country's human resources needs, or only for money-making purposes. I mean this because Ethiopia does not have much experience in crossborder distance education andsome experiences from other places are teaching us to be cautious in implementing distance education programmes."

This simply shows that all participants were not of the same opinion with regard to the quality of postgraduate distance education provided by IGNOU. In order to ensure the quality of cross-border distance education programmes in the country, an adequate policy framework for quality assurance system needs to be established.

\section{Reflections on the Findings}

There is an increasing recognition among scholars regarding the contributions of distance education in providing wider access to higher education for marginalised people. It improves the quality of the existing education system and maintains equity by democratising higher education. However, the debate around distance education calls for further improvement within this sector. Furthermore, there is almost no research work done on postgraduate level distance education in Ethiopia but within the limitations of this study, it is possible to draw certain conclusions based on the analysis of the data of the study.

The following points should be taken into consideration by IGNOU for further improvements in its programmes. The student support services which remain centralised should be decentralised as many postgraduate distance education students come from far regional areas. This was suggested by the student participants as part of the improvement plan for the institution. In addition, they also considered the fact that their final results took an average of two or three months to be returned to them to be a weakness and called for a change and improvement in this activity.

Furthermore, it can be argued that developing distance education in Ethiopia as an alternative mode of delivery in order to reach those who are marginalised and living in rural areas requires greater input from different stakeholders, including the private sector. Therefore, higher education, in general, and distance education, in particular, can be achieved through the collaboration of government, universities and the private sector.

To summarise, according to the participants of this study, collectively and individually, there are many factors that hinder the effective development of distance education. Some of the problems in developing distance education relate to the institution as well as to stakeholders' perceptions of distance education. Furthermore, the policies of national education in the country impacts on the development of distance education and cannot be ignored; they influence the narrow perception of distance education. A significant number of participants who were interviewed were aware of the importance of policy integration into distance education programmes. Therefore, it was recommended by the majority of the participants that national education policy should, more effectively, include distance education as well as the nonformal education sector. Furthermore, it was suggested that HERQA should have a clear policy framework with more autonomy and authority to be an external quality control agency for conventional and distance higher education.

The findings of this study were complemented by the results of the three chosen indices of assessment of this study, namely: coherence, efficiency and the impact of quality distance education. The three indicators were identified as major themes from which other themes were developed with corresponding sub-themes were further discussed and systematically analysed. The first part of the quality indicator of the study, known as 'coherence', was systematically analysed as it relates to the national education policies with regard to distance education development and the private sector. It was found that IGNOU followed the country's higher education policy and guidelines to operate in the country in partnership with local private higher institution. 'Efficiency', the second quality indicator, was used to assess the institution's various activities, including the quality of course materials; student support services; and learner's assessment methods. It has been commented on and analysed systematically. With regard to the third quality indicator, 'impact', was concerned with the assessment function of the various stakeholders: the MoE, HERQA and the main key players of the study, the graduates of MARD as well as prospective students and staff members. In terms of the quality of IGNOU's postgraduate studies all participants were not in agreement. To say that the quality of distance education at this level is at the desired quality standard seems to be unrealistic. However, they all agreed and acknowledged that IGNOU's provision of access to postgraduate studies had positive aspects.

\section{Conclusions}

Given the constraints of resources that many governments face in meeting the demand for higher education, distance 
education is seen as an alternative mode of delivery in providing access to quality higher education. In particular, in developing countries - including Ethiopia - that have learners in remote rural areas, distance education providers, such as IGNOU, offer educational opportunities for rural-based communities and marginalised groups who would, otherwise, not have been able to access higher education.

The overall findings demonstrate that distance education can provide access to higher education in the Ethiopian context. However, it is difficult to determine whether the quality issues are of the required standard. Rather, there is a need to encourage the institute, IGNOU, to fulfil the quality indicators proposed by the participants' in different categories of the study for further development. This study should be taken as timely and relevant in the Ethiopian context. It is further recommended that government should make a greater effort to utilise the full potential of distance education by providing policy frame work for the sector and to assure its quality issues develop quality assurance policies and, thereby, meet the various human resource development needs of the country - as suggested by the participants of the study.

\section{References}

Altbach, P. G., Reisberg, L. \& Rumbley, L. E. (2009). Trends in global higher education: Tracking an academic revolution, UNESCO.

Ashcroft, K. (2004). Emerging models of quality, relevance and standards in Ethiopia's higher education institutions. The Ethiopian Journal of Education, 23(2), 1-26.

Bogale, S. (2006). Higher education in Ethiopia. The higher education Strategy Centre, Retrieved June 2006, from HES.

Brown, R. (2000). 'The New UK quality framework', Higher Education Quarterly, 54(4), 323-342.

Cabuk, S. N. (2013). Open Courseware in Design and Planning Education And Utilization Of Distance Education Opportunity: For Architecture Education. The Turkish Online Journal of Distance Education, 10(1), 302-648.

Cheng, Y. \& Tam, W. (1997). Multi-models of Quality in Education. Journal of Education, 5(1), 22-31.

Dare, A. L. (2005). Indicators of quality. Paper presented at the National Consultative Workshop on Educational Quality Implementation in Low Income Countries. Ghana.

Department of Higher Education and Training, (2014), Policy for the provision

of distance education in South African Universities in the context of an integrated post school system, Pretoria (DHET)

Dirk, V. D. (2001). Quality issues in the internationalism of higher education: Higher Education, Academic Publishers in the Netherlands, Higher education, 4(41), 415-441.

Dooley, K. (2005). Advanced methods in distance education: Applications and Practices for educators, administrators, and learners; London: Idea Publication Group

Fayessa, D. (2010). Distance learning at the tertiary level in Ethiopia: As strategy For promoting human resource development, at the University of South Africa: (PhD thesis)

FDRE (Federal Democratic Republic of Ethiopia). (2003) \& (2009). Higher Education Proclamation No. 351/2003 and No.650/2009 Addis Ababa: Negarit Gazette.

Grant, C. (2010). From a Distance: Tutors as a Community of Practice School of Education, University of KwaZulu-Natal Abstract. Education as Change, 9(1), 80-100.

Harman, G. (2001). The politics of quality assurance: the Australian quality assurance program for higher education. Australian Journal of Education, 45(2), 168-182.

IGNOU, (2012). About Indira Gandhi National Open University: [Online...]. Available Url: http://www.ignouonline.ac.in/vel/pgccl.html [April 23, 2012].

IGNOU, (2013). Common Prospectus: [Online...]. Available Url: www.ignou.ac.in/upload/Prospectus2013-141pdf [September 27, 2013].

Jung, I. S. \& Latchem, C. (2007). Assuring quality in Asian open and distance learning. Open Learning, 22(3), 235-250.

Kishore, S. (1998). Student Support and Quality Indicators in Distance Learning. Indian Journal of Open Learning, 7(2), 205-212.

Knight, J. (2007). Cross-Border higher education: Issues and implications for quality assurance and accreditation, in Sanyal, B.C. and J Tres, Higher Education in the World 2007, Palgrave McMillan.

Knight, J. (2006). Higher Education crossing the border: A Guide to the Implications of the General Agreement on Trade in Services (GATS) for Cross-border Education, Paris, UNESCO.

Matkinw, G. (2010). The distance educators' opportunity for institutional Leadership. Continuing Higher Education. Review California, 74 (1), 32-40.

MoE, (Ministry of Education). (2003 and 2007). Education Statistics Annual Abstract. Addis Ababa: Federal Democratic Republic of Ethiopia.

MoE, (2011/2012). Ministry of Education Annual Abstract. Addis Ababa. Federal Democratic Republic of Ethiopia.

Morley, L. (2000). The micro politics of gender in the learning society. Higher Education in Europe, 25(2), 229-235.

Mills, D. (2006). Those who can....? Teaching as a postgraduate. In: N. Gilbert (Ed.), From Postgraduate education journal to Social Scientist: A Guide to Key Skills. London: Sage.

Musisi, N. (2003). Uganda. In D. Teferra \& P. G. Altbach (Eds.), African

Higher Education: An international reference handbook (pp. 611-623). Bloomington, Indiana, USA: Indiana University Press. 
Nuan, T. (1996). Distance Education: What is it and can have educational future? In: Keegan,D. (Ed.). Theoretical principles of distance education. London: Routledge.

Nwuke, K. (2008). The private provision of higher education in Ethiopia: Growth, Challenge, and prospective. Council for the Development of Social Science Research in Africa, United Nations Economic Commission for Africa, Addis Ababa, 6 (1), 71-94.

Perraton, H. (2000). Open and Distance Learning in developing world: Published, London: Rutledge

Pityana, N. B. (2004). Distance education in Africa: Dome challenges and perspectives. Paper presented at the Annual Conference of NADEOSA: The potential of mixed mode delivery', St John's College, Johannesburg.

Roper, C. \& Shaw, M. (Eds). (1993). Quality in Education: Aspects of education and training. London, New Jersey: Kogan Page.

Sharma, R. C. (1997). Distance Education in Global Perspectives. University News, volume 35(46) pp.12.

Taylor, J. (2001). Fifth Generation Distance Education. Report No. 40. Higher Education Series, Department of Education, Training, University of South Queensland.

Teferra, D. (2014). Charting African Higher Education: Perspectives at a glance. International Journal of African Higher Education. Vol1 No1 pp. 9-21.

Tesfaye, S. (2010). Adult and continuing education in post-secondary education in Ethiopia: Policy, practice, and challenges, Hawassa, Journal of Social Sciences, 13(1), 34 .

Thomas, D. H. (2008). Managing Human Capital: Global Trends and Challenges. Harvard Business School, Global Business Summit. UNISA, (2011). UNISA ETHIOPIA Newsletter: Ethiopia Regional Learning Centre and stakeholders. Addis Ababa, Ethiopia, 2(11), 5-11. Vroeijenstijn, T. (2006). Similarities and Differences in Accreditation: looking for a Common framework. Prepared for the workshop on the establishment of European Consortium for Accreditation (ECA). The Hague. Available at http://www.fibaa.de/ger/downlo/ Similarities \& Differences.pdf 